\title{
Working Capital Management
}

\author{
R. Ramamoorthy, M.Sangeetha, A.Kamal
}

\begin{abstract}
Preferably, there would be no requirement for rhythmic movement assets and liabilities in light of the way that there would be no weakness, no trade costs, information search costs, arranging costs, or creation and advancement goals. The unit cost of age would not vary with the sum made. Getting and crediting rates will be same. Capital, work, and thing business sector will be flawlessly forceful and would reflect every single available datum, as such in such a circumstance, there would be no good position for placing assets into transitory assets. Additionally every affiliation is looked with its own one of a kind purposes of control on as far as possible and advances it can use there are fixed similarly as factor costs related with creation stock. Toward the day's end, the business divisions where certifiable firm worked are not flawlessly engaged. [1],[3],[5]

Keywords :tax,mamagement,assets
\end{abstract}

\section{INTRODUCTION}

These genuine conditions present issue's which require the need of keeping up working capital. For example, an affiliation may be looked with a defenselessness concerning availability of satisfactory measure of essential commitments to future at reasonable expense. This may require the holding of stock, current assets. So likewise an affiliation may be looked with a helplessness concerning the level of its future cash streams and insufficient proportion of cash may achieve critical costs. This may require the holding of spare of flitting alluring insurances, again a transient capital asset. In corporate budgetary organization, the term working capital organization addresses the excess of current assets over current liabilities. [2 ],[ 4],[6]

\section{A. WORKING CAPITAL}

In basic words working capital is the overabundance resources over current liabilities. Working capital has usually been characterized as the overabundance of current resources over current liabilities. Working capital is the core of the business. In the event that it is powerless business can't legitimate and endures. It is accordingly said the destiny or huge scale interment in fixed resources is regularly dictated by a generally modest quantity of current resources. As the working capital is imperative to the organization is essential to keep satisfactory working capital with the organization. Money is the help of organization. [7],[ 9] ,[11]

Revised Manuscript Received on July 22, 2019.

R.Ramamoorthy, Department of MBA, Bharath Institute of Higher Education and Research, Tamilnadu, India. Email: ramamoorthy0071@gmail.com

M.Sangeetha, Department of MBA, Bharath Institute of Higher Education and Research, Tamilnadu, India. Email: sangeethagiri07.sg@gmail.com

Dr.A.Kamal, Department of EEE, Bharath Institute of Higher Education and Research, Tamilnadu, India. Email: ak2-anvi@yahoo.co.in
The objective of working capital administration is to guarantee that a firm can proceed with its activity. Also, that is has adequate capacity to fulfill both developing short working capital, the less the organization needs to acquire. Indeed, even organizations with money surpluses need to oversee working cash-flow to guarantee those surpluses are put resources into ways that will create reasonable returns for financial specialists. The essential goal of working capital administration is to guarantee that adequate money is accessible to [8],[10],[12]

- Meet everyday income needs

- Pay wages and pay rates when they fall due

- Pay banks to guarantee proceeded with provisions of merchandise and ventures.

- Pay government tax collection and supplier of capital-profits and

- Ensure the long haul survival of the business element. [13], [15] ,[ 17]

\section{B. TOOLS}

- Ratio analysis

- Schedule of changes in working capital

- Trend analysis

\section{DATA ANALYSIS AND INTERPRETATION}

\begin{tabular}{|c|c|c|c|}
\hline YEAR & CURRENT ASSETS & $\begin{array}{l}\text { CURRENT } \\
\text { LIABILITIES }\end{array}$ & RATIO \\
\hline $2007-2008$ & 18335520 & 5797632 & 3.16 \\
\hline $2008-2009$ & 14636269 & 6650145 & 2.20 \\
\hline $2009-2010$ & 9126380 & 8040640 & 1.13 \\
\hline $2010-2011$ & 5323215 & 2564200 & 2.07 \\
\hline $2011-2012$ & 3769243 & 2802760 & 1.34 \\
\hline
\end{tabular}

Fig:1 GRAPHICAL REPRESENTATION OF CHANGE OF DIRECTION OFCURRENT RATIO

Table : 2 Liquidity Ratio

\begin{tabular}{|l|l|l|l|}
\hline YEAR & LIQUID ASSETS & $\begin{array}{l}\text { LIQUID } \\
\text { LIABILITIES }\end{array}$ & RATIO \\
\hline $2007-2008$ & 2531199 & 5797632 & 0.44 \\
\hline $2008-2009$ & 14257552 & 6650145 & 2.14 \\
\hline $2009-2010$ & 3257176 & 8040640 & 0.41 \\
\hline $2010-2011$ & 1024750 & 2564200 & 0.40 \\
\hline $2011-2012$ & 830208 & 2802760 & 0.30 \\
\hline
\end{tabular}




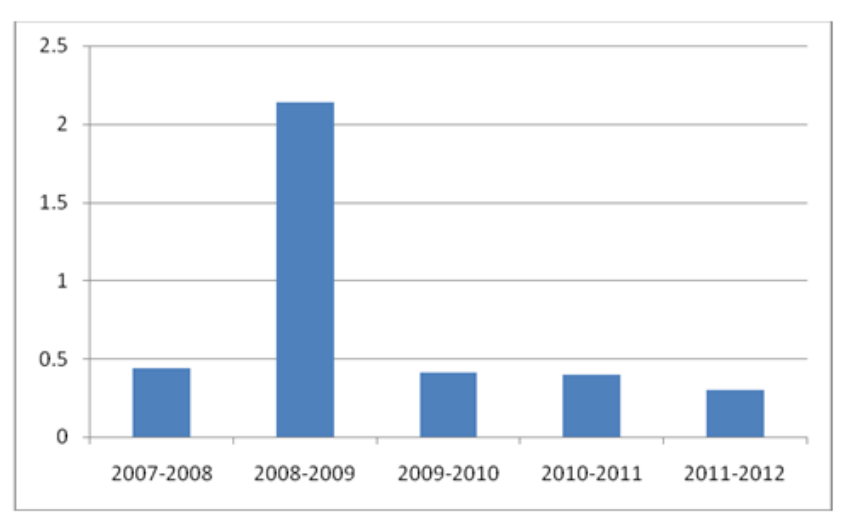

Fig:2 REPRESENTATION OF CHANGE OF DIRECTION OFLIQUIDITY RATIO

TABLE :3 LIQUID RATIO

\begin{tabular}{|l|l|l|l|}
\hline YEAR & $\begin{array}{l}\text { ABSOLUTE } \\
\text { LIQUID ASSET }\end{array}$ & $\begin{array}{l}\text { CURRENT } \\
\text { LIABILITY }\end{array}$ & RATIO \\
\hline $2007-2008$ & 17332292 & 5797632 & 2.98 \\
\hline $2008-2009$ & 13574946 & 6650145 & 2.04 \\
\hline $2009-2010$ & 8638025 & 8040640 & 1.07 \\
\hline $2010-2011$ & 4913050 & 2564200 & 1.91 \\
\hline $2011-2012$ & 2984728 & 2802760 & 1.06 \\
\hline
\end{tabular}

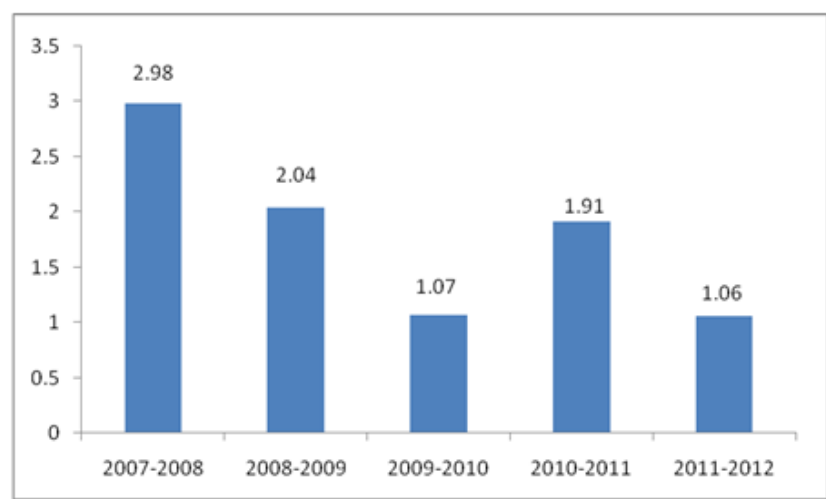

Fig: 3 GRAPHICAL REPRESENTATION OF CHANGE OF DIRECTION OF ABSOLUTE LIQUID RATIO

TABLE:4 DEBT EQUITY RATIO

\begin{tabular}{|l|l|l|l|}
\hline YEAR & $\begin{array}{l}\text { TOTAL LONG } \\
\text { TERM DEBT }\end{array}$ & $\begin{array}{l}\text { SHARE } \\
\text { HOLDER FUND }\end{array}$ & RATIO \\
\hline $2007-2008$ & 14149016 & 8141622 & 1.74 \\
\hline $2008-2009$ & 9438667 & 6193427 & 1.52 \\
\hline $2009-2010$ & 5485825 & 2208803 & 2.48 \\
\hline $2010-2011$ & 6396102 & 3119080 & 2.05 \\
\hline $2011-2012$ & 6773896 & 3494580 & 1.93 \\
\hline
\end{tabular}

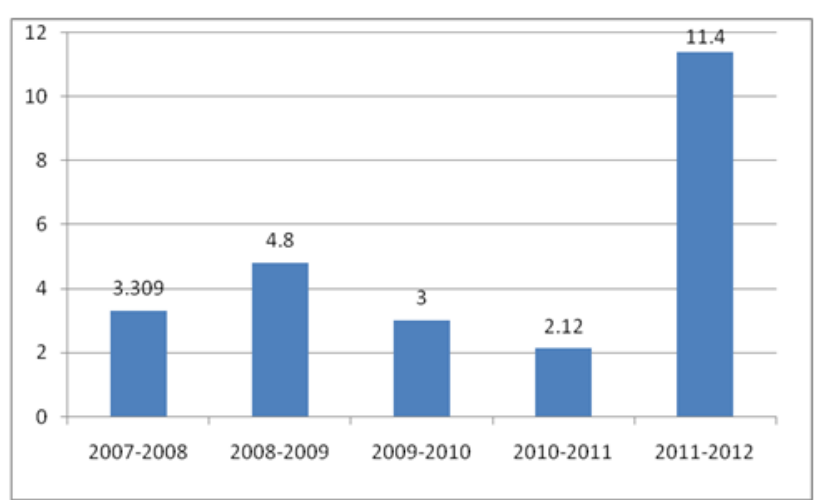

Fig:5 GRAPHICAL REPRESENTATION OF CHANGE OF DIRECTION OF GROSS PROFIT RATIO

TABLE :6 NET PROFIT RATIO

\begin{tabular}{|l|l|l|l|}
\hline YEAR & NET PROFIT & SALES & RATIO \\
\hline $2008-2009$ & 449387 & 13249222 & 3.3 \\
\hline $2009-2010$ & 319236 & 19162921 & 1.66 \\
\hline $2010-2011$ & 502277 & 18442077 & 2.72 \\
\hline $2011-2012$ & $307860 \mathrm{a}$ & 24904265 & 1.23 \\
\hline
\end{tabular}

Fig: 4 GRAPHICAL REPRESENTATION OF CHANGE OF DIRECTION OF DEBT EQUITY RATIO

\section{TABLE:5 GROSS PROFIT RATIO}

\begin{tabular}{|l|l|l|l|}
\hline YEAR & GROSS PROFIT & SALES & RATIO \\
\hline $2007-2008$ & 3126797 & 94466423 & 3.309 \\
\hline $2008-2009$ & 636422 & 13249222 & 4.8 \\
\hline $2009-2010$ & 575495 & 19162921 & 3 \\
\hline $2010-2011$ & 391952 & 18442077 & 2.12 \\
\hline $2011-2012$ & 2854140 & 24904265 & 11.4 \\
\hline
\end{tabular}




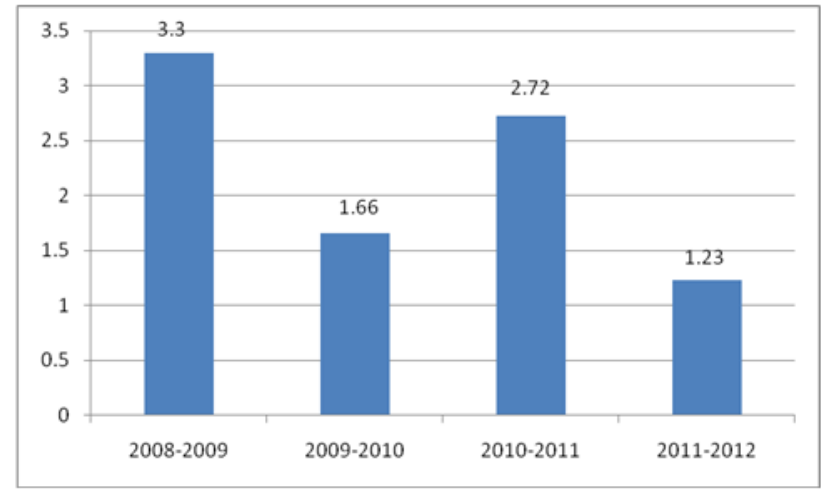

Fig:6 GRAPHICAL REPRESENTATION OF CHANGE OF DIRECTION OF NET PROFIT RATIO

Table:7 OPERATING RATIO

\begin{tabular}{|l|l|l|l|}
\hline YEAR & $\begin{array}{l}\text { COST OF GOODS } \\
\text { SOLD+OPERATING } \\
\text { EXPENSES }\end{array}$ & SALES & RATIO \\
\hline $2007-2008$ & 92972580 & 94466423 & 98.41 \\
\hline $2008-2009$ & 13618484 & 13249222 & 102.78 \\
\hline $2009-2010$ & 19763084 & 19162921 & 103.13 \\
\hline $2010-2011$ & 19225825 & 18442077 & 104.24 \\
\hline $2011-2012$ & 23506075 & 24904265 & 94.3 \\
\hline
\end{tabular}

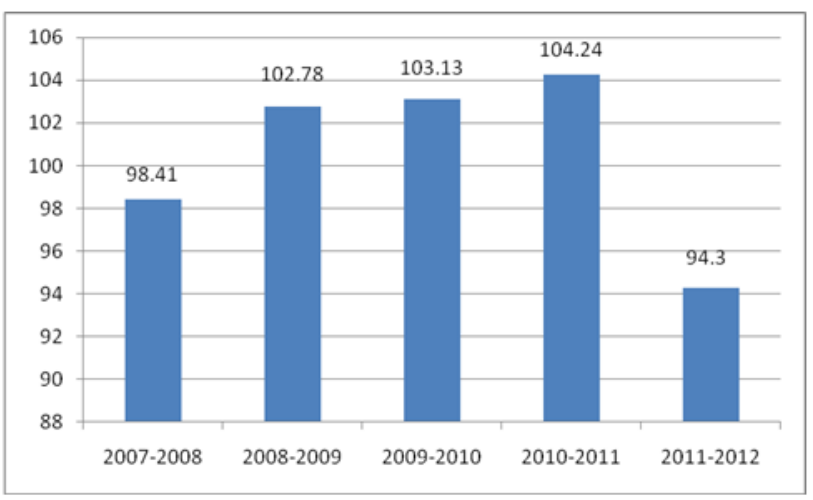

Fig: 7 GRAPHICAL REPRESENTATION OF CHANGE OF DIRECTION OF OPERATING RATIO

Table:8 CAPITAL TURNOVER RATIO

\begin{tabular}{|l|l|l|l|}
\hline YEAR & SALES & $\begin{array}{l}\text { CAPITAL } \\
\text { EMPLOYED }\end{array}$ & RTATIO \\
\hline $2007-2008$ & 94466423 & 13576835 & 6.95 \\
\hline $2008-2009$ & 13249222 & 9016387 & 1.469 \\
\hline $2009-2010$ & 19162921 & 4976206 & 3.85 \\
\hline $2010-2011$ & 1844077 & 5782900 & 0.31 \\
\hline $2011-2012$ & 24904265 & 11149563 & 2.23 \\
\hline
\end{tabular}

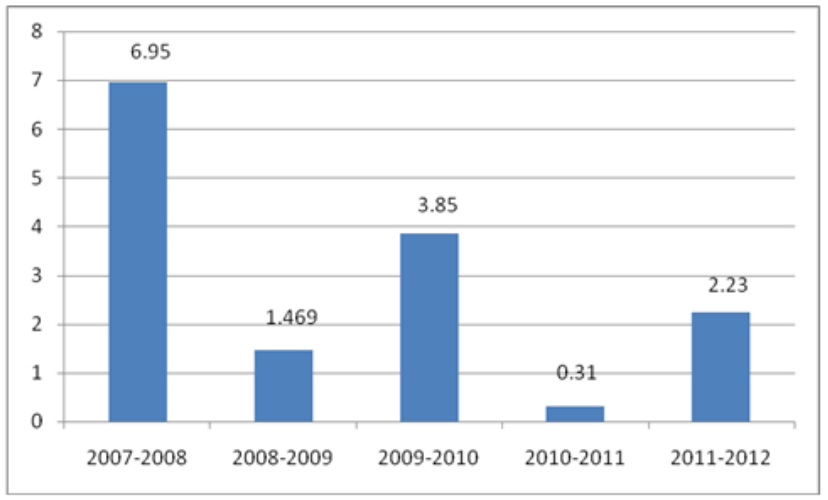

Fig:8 GRAPHICAL REPRESENTATION OF CHANGE OF DIRECTION OFCAPITAL TURNOVER RATIO

Table:9 STOCK TURNOVER RATIO

\begin{tabular}{|l|l|l|l|}
\hline YEAR & SALES & $\begin{array}{l}\text { AVERAGE } \\
\text { INVENTORY }\end{array}$ & RATIO \\
\hline $2007-2008$ & 94466423 & 3495598 & 27.2 \\
\hline $2008-2009$ & 13249222 & 1109156 & 11.94 \\
\hline $2009-2010$ & 19162921 & 714462 & 26.82 \\
\hline $2010-2011$ & 1844077 & 364030 & 5.06 \\
\hline $2011-2012$ & 24904265 & 449940 & 55.35 \\
\hline
\end{tabular}

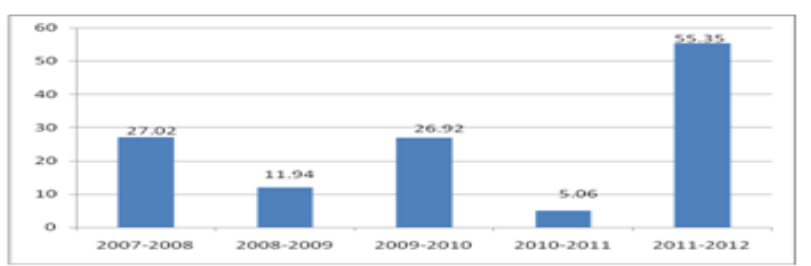

Fig:9 GRAPHICAL REPRESENTATION OF CHANGE OF DIRECTION OFSTOCK TURNOVER RATIO

Table:10 TREND ANALYSIS FOR NEXT FIVE YEARS WORKING CAPITAL FOR THE NEXT FIVE YEARS BASED ON THE METHOD OFLEAST SQUARES

\begin{tabular}{|l|l|l|}
\hline Year & $\mathrm{X}$ & Trend Values $(\mathrm{y}=34044981.6+27305577.7 \mathrm{X})$ \\
\hline 2013 & 3 & $34044981.6+27305577.7(3)=1159617147$ \\
\hline 2014 & 4 & $34044981.6+27305577.7(4)=143267292$ \\
\hline 2015 & 5 & $34044981.6+27305577.7(5)=170572870.1$ \\
\hline 2016 & 6 & $340449816+27305577.7(6)=197878447.8$ \\
\hline 2017 & 7 & $34044981.6+27305577.7(7)=225184025.5$ \\
\hline
\end{tabular}




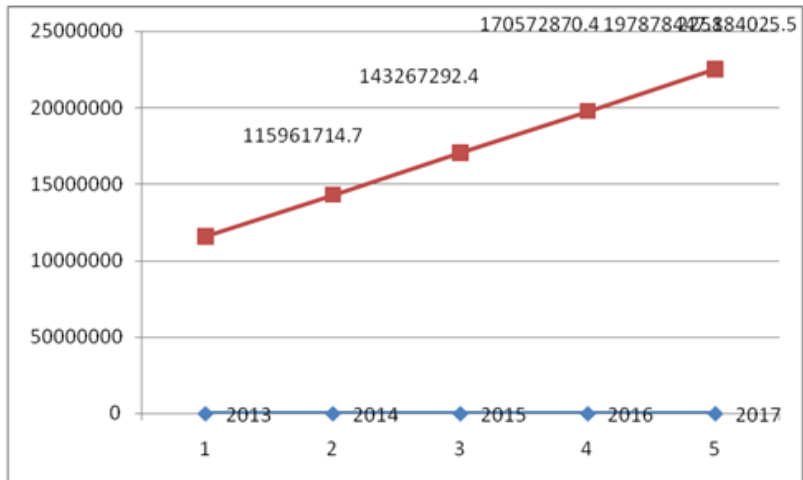

Fig:10 GRAPHICAL REPRESENTATION OF CHANGES OF DIRECTION OF TREND ANALYSIS FOR THE NEXT FIVE YEARS

\section{RESULTS}

The findings revealed from the analysis of data in the previous chapter is summarised as below[19],[21],[23]

$\square$ The current proportion is changing ceaselessly and it was low (1.13) during the period 2009-2010 and it increment to (3.16) during the period 2007-2008. As examined the proportion was less a direct result of the administration restricted the fare of rice and dhall things. [31],[33],[32]

$\square$ The fluid proportion is changing constantly and it was low (0.30) during the period 2011-2012 and it increment to (2.14) during the period 2008-2009. As we broke down the proportion we can see that in 2008-2009 the fluid proportion was high a direct result of high nearby deals.

$\square$ The obligation value proportion changing ceaselessly and it was low (1.52) during the period 2008-2009 and it increment to (2.48) in the year 2009-2010. As we investigated obligation value proportion was exceptionally less because of defer installment by the collector of the products.

The gross benefit proportion persistently and it was low (2.12) during the period 2010-2011 and it increment to (3.309) during the period (2007-2008). As we think about the gross benefit proportions of consistently it tends to be seen that in 2011-2012 it is exceptionally high in light of high fare deals.

$\square$ The net benefit is changing consistently and it was low (1.23) during the period 2011-2012 and it increment to 3.3 during the period 2008-2009. As contrasting the net benefit of most recent multiyear it is seen that the fare was done appropriately.

The working proportion is changing constantly and it was low (94.3) during the time of 2011-2012 and it increment to (104.24). As we investigated the working proportion was not done appropriately during the year 2011-2012 due to neighborhood buy was low.

$\square$ The capital turnover proportion is changing persistently and it was low (0.3) during the period 2010-2011 and it increment to 6.95 during the period 2007-2008. As we broke down capital turnover proportion is because of un solidness of nearby deals ,trade deals deferred installment and government exercises [14], [ 16], [18] $\square$ The stock turnover proportion is changing consistently and it was low (5.06) during the time of 2010-2011 and it increment to (55.35) during the period 2011-2012. The organization needs to make satisfactory move to expand the stock level in the extent to expanding deal.

$\square$ The working capital proportion is changing constantly and it was low(0.16) during the period and it increment to (25.76) during the period 2011-2012. As we think about the working capital turnover proportion in the year 2011-2012 was high a direct result of the fare deals neighborhood deals was more and the installment was likewise on schedule.

The working capital prerequisite of the organization to complete the creation design is attractive and isn't experiencing any insufficiency. The pattern examination will appear next five years of working capital. It showing the organization working capital position is expanded for next multi year from 2012 to 2017.

\section{DISCUSSION}

The organization is added to the present resources and liabilities.

The organization needs to raise the long haul speculation and use the present resources.

$\square$ The money position of the organization has not been appropriately kept up. So the organization needs to try to diminish the costs and furthermore money to current resources proportion. [26],[28],[30]

$\square$ Increase the bank parity and speculation to build the estimation of all out resources of the organization.

$\checkmark$ Increase the deals and diminish the expense of merchandise offered to get increasingly gross benefit of the business.

The organization might be concentrate to keep up the liquidity position on money balance.

$\square$ The organization might confine credit to client who consistently makes default in their installments. This will empower the organization to pay off it awful obligations.

$\square$ The organization is added to trade the sustenance things in an ideal time which will prompt a more benefit. Since for each decrease of outside conversion standard the Indian cash worth increments. [20], [22], [24]

\section{V.CONCLUSION}

The objective of working capital administration is to deal with the association's present resources and current liabilities so that an agreeable degree of working capital is kept up the significance of working capital administration is reflected administrators spend an in that the money chiefs invest a lot of energy in dealing with the present resources and current liabilities. Orchestrating momentary financing, arranging positive credit terms, controlling the development of money, regulating the record receivable and checking the speculation, devour a lot of time for the account supervisors. Each business firm needs to keep up a satisfactory degree of working cash-flow to maintain the business easily without money crunch. The present examination

demonstrated that the working capital position of this organization is in an 
agreeable position and there is an expanding pattern for the future time frame. [25],[27],[29]

\section{REFERENCES}

1. G BharthVajan R., Ramachandran S.,Psychographic dimensions of training,2016,International Journal of Pharmacy and Technology,V-8,I-4,P-23727-23729

2. Balakrishnan P., Bharthvajan R.,A study on human resource planning in hospitals in Chennai City,2014,International Journal of Applied Engineering Research,V-9,I-22,P-7503-7507

3. Priyadarsini P., Bharthvajan R.,Role of emotional intelligence training programme in reducing the stress of the nurses,2014,International Journal of Applied Engineering Research,V-9,I-22,P-7411-7421

4. Kerinab Beenu G., Bharthvajan R.,Empirical analysis on the cosmetic buying behavior of young women in South India,2014,International Journal of Applied Engineering Research,V-9,I-22,P-7361-7366

5. Balakrishnan P., Bharthvajan R.,Whistling in the wind,2014,International Journal of Applied Engineering Research,V-9,I-22,P-7586-7593

6. Krishnan B., Peter M.,Health hazards of Indian Bpo employee-an alarming issue,2014,International Journal of Applied Engineering Research,V-9,I-22,P-7336-7341

7. Kerinab Beenu G.H., Peter M.,Role of insurance in economic development,2014,International Journal of Applied Engineering Research,V-9,I-22,P-7532-7539

8. Balakrishnan P., Peter M., Priyadarsini P.,Efficiency of safety measure for wellbeing of employees in manufacturing industry,2014,International Journal of Applied Engineering Research,V-9,I-22,P-7376-7382

9. Anbarasi M., Praveen Kumar S.,Online sales promotions of herbal products and its effectiveness towards tanisha.com,2019,Indian Journa of Public Health Research and Development,V-10,I-1,P-195-200

10. Anbarasi M., Praveen Kumar S.,Various online marketing and promotions strategies to improve the validation towards the organic products in the pharmaceutical sectors,2019,Indian Journal of Public Health Research and Development,V-10,I-1,P-263-269

11. Loganathan R., Praveen Kumar S.,Grievance handling a key factor for solving issues of employees in an organization,2014,International Journal of Applied Engineering Research,V-9,I-22,P-7483-7491

12. Loganathan R., Praveen Kumar S.,Study on preference of private labe brands in super and Hypermarkets,2014,International Journal of Applied Engineering Research,V-9,I-22,P-7327-7335

13. Smitha M., Praveen Kumar S.,Understanding stress and its managementamong the nurses in Chennai city,2014,International Journal of Applied Engineering Research,V-9,I-22,P-7560-7565

14. Kerinab Beenu G.H., Praveen Kumar S.,A study on the investment behavior of Chennai investors in mutual fund schemes, 2014,International Journal of Applied Engineering Research,V-9,I-22,P-7520-7525

15. Loganathan R., Praveen Kumar S.,Retention strategies key for organizational productivity,2014,International Journal of Applied Engineering Research,V-9,I-22,P-7443-7447

16. Pavithra J., Ganesan M., Brindha G.,State wise analysis of microfinance sector in India,2016,International Journal of Pharmacy and Technology,V-8,I-4,P-23417-23432

17. Pavithra J., Ganesan M.,A comparative study on microfinance in India and abroad,2016,International Journal of Applied Business and Economic Research,V-14,I-8,P-5471-5476

18. Pavithra J., Ganesan M.,A study on awareness and impact of micro-financial schemes,2016,International Journal of Applied Business and Economic Research,V-14,I-8,P-5449-5460

19. Senthilmurugan P., Pavithra J.,Consumer preference towards organised retailing with reference to Big Bazaar,2014,International Journal of Applied Engineering Research,V-9,I-22,P-7469-7475

20. Senthilmurugan P., Pavithra J.,Implication of social media marketing in growing healthcare industry,2014,International Journal of Applied Engineering Research,V-9,I-22,P-7448-7456

21. Loganathan R., Pavithra J.,Consumer perception towards private label brand over other brands in super markets and hypermarkets,2014,International Journal of Applied Engineering Research,V-9,I-22,P-7355-7360

22. Kerinab Beenu G., Pavithra J.,Tradeâ€"off between liquidity and profitability in logistics industry,2014,International Journal of Applied Engineering Research,V-9,I-22,P-7398-7401

23. Kerinab Beenu G., Pavithra J.,A study on the prospective consumerâ€ $\mathfrak{T M}_{\mathrm{S}}$ perception towards utility cars in Chennai city,2014,International Journal of Applied Engineering Research,V-9,I-22,P-7526-7531

24. Pavithra J., Dilli Babu P., Ambuli T.V.,A study on budgetary control at Maruti Service Masters, Chennai,2014,International Journal of Applied Business and Economic Research,V-12,I-2,P-151-161
25. Pavithra J., Dilli Babu P., Ambuli T.V.,A study on customer satisfaction of retro Garments Pvt Ltd, Chennai,2014,International Journal of Applied Business and Economic Research,V-12,I-2,P-381-391

26. Kerinab Beenu G.H., Pavithra J., Senthilmurugan P.,A study on the influence of promotional activities for TATA ARIA among consumers in Chennai,2014,International Journal of Applied Engineering Research,V-9,I-22,P-7572-7578

27. Vijayaragavan S.P.,An investigative expert that's general FBG sensors,International Journal of Mechanical Engineering and Technology,V-8,I-8,PP-1500-1505,Y-2017

28. Vijayaragavan S.P.,Equalization routing protocol for Wi-Fi sensor strategy,International Journal of Mechanical Engineering and Technology,V-8,I-8,PP-1662-1666,Y-2017

29. Karthik B., Kiran Kumar T.V.U., Vijayaragavan P., Bharath Kumaran E.,Design of a digital PLL using 0.35 $\hat{\mathrm{I}}^{1 / 4 \mathrm{~m}}$ CMOS technology,Middle East Journal of Scientific Research,V-18,I-12,PP-1803-1806,Y-2013

30. Kanniga E., Selvaramarathnam K., Sundararajan M.,Kandigital bike operating system,Middle - East Journal of Scientific Research,V

31. Jasmin M., Vigneshwaran T., Beulah Hemalatha S.,Design of power aware on chip embedded memory based FSM encoding in FPGA,International Journal of Applied Engineering Research,V-10,I-2,PP-4487-4496,Y-2015

32. Jasmin M.,Optimization techniques for low power VLSI circuits,Middle East Journal of Scientific Research,V-20,I-9,PP-1082-1087,Y-2014

33. Jasmin M., Vigneswaran T.,Fuzzy controller for error control of on - Chip communication,2017 International Conference on Algorithms, Methodology, Models and Applications in Emerging Technologies, ICAMMAET 2017,V-2017-January,I-,PP-1-5,Y-2017

\section{AUTHORS PROFILE}

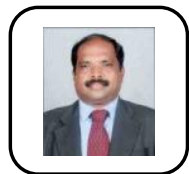

Ramamoorthy,Assistant Professor ,Department of MBA, Bharath Institute of Higher Education and Research, Tamilnadu, India

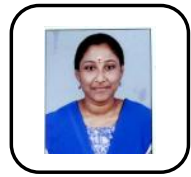

Sangeetha M Assistant Professor ,Department of MBA, Bharath Institute of Higher Education and Research, Tamilnadu, India

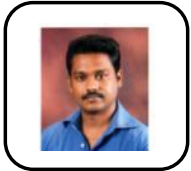

Dr.A.Kamal Associate Professor ,Department of EEE Bharath Institute of Higher Education andResearch, Tamilnadu, India 